\title{
RICHARD DAINTREE, C.M.G., F.G.S.
}

Born December, 1831. Died June 20, 1878.

Australian Geologr has sustained another severe loss in the death of Mr. R. Daintree, C.M.G., F.G.S., following, as it has done, so rapidly on that of the Rev. W. B. Clarke, F.R.S.'

Richard Daintree was born at Hemingford Abbotts, Huntingdonshire, in December, 1831, and was educated at the Bedford Grammar School, and Christ's College, Cambridge. In consequence of delicate health, Mr. Daintree was recommended a voyage to Australia, and he accordingly set sail for Melbourne, where he landed in the latter part of 1852. A taste for scientific pursuits brought him in contact with Mr. A. R. C. Selwyn, the Government Geologist of Victoria, whose Assistant he became in 1854; but finding that a more practical acquaintance with Chemistry and Assaying, than he at that time possessed, would prove beneficial to his prospects, he returned to England in 1856, and entered Dr. Percy's Laboratory. Here he worked from November, 1856, to May, 1857, and became a practised and efficient assayer, to which he added a knowledge of practical photographic chemistry.

In August, 1857, Mr. Daintree returned to Melbourne, and in 1858 was appointed Field-Geologist on the Geological Survey of Victoria, which had by this time been established on a firm basis through the energy of its Director, Mr. A. R. C. Selwyn, F.R.S. During his connexion with the Victorian Survey, for the next seven years, Mr. Daintree was occupied in field work and exploration of no ordinary nature. He commenced in the Western-port district, directing his attention to the Cape Patterson Coal Series. In exploring the Bass River, Daintree underwent much hard camp life, and endured many privations in penetrating the dense scrubs of that district.

The Geology of the Bellerine District ${ }^{2}$ next engaged Mr. Daintree's attention, lying between Geelong and Queenscliff. A series of extensive borings for Coal, through the Mesozoic rocks, were there superintended; but, although about 4000 feet of strata were passed through, the search was fruitless. On leaving Bellerine in 1861, Mr. Daintree was joined by Mr. C. S. Wilkinson (now Government Geologist for N. S. Wales) as his Assistant, and until March, 1864, they were conjointly engaged in the geological survey of the country from Bass' Straits on the south, to Bacchus Marsh on the north, including the important agricultural and pastoral districts of the Barrabool Hills, the Annakie Hills, the Werribee River and Ballan district. At the end of May, 1863, a most important report was prepared by Mr. Daintree, on this work, and when published it

1 See Obituary Notice of Rev. W. B. Clarke, Geor. MaG. Angust, p. 379.

2 Report on the Geology of Bellerine and Pagwit, with Special Reference to the probable Existence of workable Coal Seams in those Parishes. By R. Daintree.Vict. Geol. Survey Report, 1861-62, No. 43, folio, pp. 16-23. Melbourne.

Maps.-Sheet 23 N.E. (Portarlington); 23 S.E. (St. Leonards); 23 S.W. (Point Henry); Sheet 29 N.E. (Queenscliff); 29 N.W. (Lake Connewarre). By i. Daintree, under the direction of A. R. C. Selwyn. 
was prefaced with the following official remarks: "The following interesting Report .... contains so much matter having an immediate reference to the economic development of the Colony, interwoven with purely scientific observations, that it has been deemed desirable to publish it in extenso, without waiting to produce it in connexion with a series of similar reports or memoirs," etc.

Some of the less known parts of Victoria were explored by Messrs. Selwyn and Daintree in company, and on one of these trips a tour of the gold-fields was made, and many most interesting photographs illustrative of gold-field geology were taken.

In 1864 Daintree resigned his connexion with the Victorian Civil Service, and entered into pastoral pursuits on the River Clarke, Burdekin River, North Queensland; but during one of the several trips made by him about that time between Melbourne and the northerm colony, he found time to make a partial examination of the N. S. Wales Coal-field. The results of his observations ${ }^{1}$ are important, because they tended in a great measure to support the views held by the late Rev. W. B. Clarke on the age and position of the Coalmeasures of N. S. Wales. Notwithstanding the danger and hardships of a "squatting" life in lat. $19^{\circ} \mathrm{S}$., Mr. Daintree's geological studies were not neglected, for several useful examinations of his own district were made. In 1866 a paper was read by him before the Royal Society of N. S. Wales, to the effect that auriferous tracts would be found in the neighbourhood of the Endeavour River, a statement which was borne out eight years later by the discovery of the Palmer Gold-field.

The full report, ${ }^{2}$ previously referred to, bearing on the work done by Daintree and Wilkinson in the Ballan district of Victoria, was not published in detail until 1866, when it appeared as one of the regular reports of the Survey. In this report Daintree discussed at some length the various modes of occurrence of gold, and in reference to the origin of the precious metal, he said: "I had long ago come to the conclusion, that most, if not all, the gold in the quartz reefs was derived from the rocks in which these reefs occur. That the strata themselves received their supply of gold at the period of their deposition from the ocean in which they were deposited. That organic matter, and the gases generated therefrom on decomposition, sulphuretted hydrogen, etc., was the cause of the precipitation, and that the amount of metallic deposit was in proportion to the amount of organic matter deposited with the oceanic

1 On the Age of the N. S. Wales Coal-beds. By R. Daintree.-The Geologist, 1864, vol. vii. pp. $72-79$.

2 Report on the Geology of the District of Ballan, including Remarks on the Age and Origin of Gold. By R. Daintree. Vict. Geol. Survey Report, 1866, No. 15, pp. 11, tolio. Melbourne.

Maps:-Sheet 8 S.E. (Tarneit) ; 8 S.W. (Mount Mary); Sheet 12 S.E. (Balliang); Sheet 19 N E. (Annakie Hills); 19 S.E. (Station Peak); 20 N.W. (You-Yangs); $20 \mathrm{~S} . \mathrm{W}$. (Rothwell); Sheet 23 N.W. (Point Wilson, etc.); Sheet 24 S.E. (Geelong); Sheet 28 N.E. (German Town); and Sheet 29 S.W. (Thompson's Creek). BJ R. Daintree and C. S. Wilkinson, etc. 
sediment. The subsequent plication and desiccation of the sediment caused fissures, into which the mineral waters percolating, the boundary rocks flowed and were decomposed, and their mineral contents were precipitated, possibly by magnetic currents, thus causing mineral veins."

The geological and other scientific acquirements of Richard Daintree were not lost upon the Queensland Government, for in 1867 they requested him to make an examination of the Cape River district, which resulted in the opening up of the Cape River Gold-field.' In 1869 he was appointed Government Geologist for North Queensland, whilst the late Mr. C. D'Oyley H. Aplin was appointed to a similar post in the southern part of the same colony. The Queensland Government were able to secure the latter gentleman's services through the parsimony of the authorities of the Victorian Colony in breaking up one of the most complete Geological Surveys ever organized, except perhaps that of the United States Territories, under Dr. F. V. Hayden. During the three years intervening between 1869-71, Mr. Daintree examined large areas in North Queensland, including those of the Gilbert ${ }^{2}$ and Etheridge Rivers, and the Ravenswood district, which have since proved highly auriferous and remunerative to those employed on them.

The importance of proper and efficient representation at the London Exhibition of 1872 was not lost upon the Queenslanders, for in 1871 Mr. Daintree was appointed Special Commissioner, and in consequence left the colony. The wisdom of the Colonial Government's selection cannot be better borne out than by the admirably organized and arranged Queensland Annexe of that and succeeding Exhibitions, in the administration of which Mr. Daintree took the entire superintendence and most active part, although latterly much broken in health. The office of Agent-General in London to the Colony of Queensland falling vacant at this time, the subject of our notice was appointed to it in March, 1872, a post held by him until 1876, when, in consequence of ill health, he was obliged to resign. It is gratifying to find that the services rendered by Mr. Daintree to the Colony in his official capacity, and to Colonial Science generally, were so far recognized by the Home Authorities, that it pleased Her Majesty, on his retirement, to confer on him the well-merited honour of C.M.G. It was hoped by his friends that rest and change would, to some extent at least, restore his shattered health, but notwithstanding a residence at Mentone during the winters of 1876 and 1877 , and all that professional attention and affectionate family care could do, he gradually sank, and shortly after reaching this country in May last, he passed away. In a letter to a mutual friend dated Mentone, November, 1876, Daintree wrote thus:- "Thanks to hard work and rough food in a tropical climate, I managed to damage my liver, so

1 Report on the Cape River Diggings and the Latest Mineral Discoveries in North Queensland. By R. Daintree. Folio, pp. 7. Map. Brisbane.

2 Report on the Gold Discoveries in the Gilbert Ranges, with Sketch Map. By R. Daintree. Folio, Brisbane, 1869. Report on the Gilbert Ranges Goldfield, with Maps. By R. Daintree. Folio, Brisbane, 1869. 
that I am now a martyr to chronic dyspepsia; and, thanks to sedentary employment in London, and the fog and damp of the English climate, I managed to get congestion of the lungs, with more or less hæmorrhage several times, so that, at an age when I ought to be arailing myself of my accumulated experience in various ways, I find myself a confirmed invalid, cut off from all active enterprise whatever."

A large proportion of the valuable results of Daintree's work in Australia were nearly lost through the wreck of the ship (on board which he and his collections were stowed) at the Cape of Good Hope. Fortunately, however, the cases were recovered, and their contents supplied the material for the most exhaustive paper yet publisbed ${ }^{1}$ on Queensland Geology. One of the chief points there brought out was the great extent of ground occupied by rocks of Cretaceous age in the north of Australia, for although Cretaceous fossils had been determined some years before by Prof. M'Coy, Mr. Daintree appears to have been the first to point out the extent of the beds containing them. During the last few years of his life, when incapacitated by illness from active exertion, the microscope afforded Mr. Daintree much enjoyment, his attention being particularly directed to the subject of Petrology, more particularly as applied to Queensland rocks. We are informed that at the time of his death he had in preparation an important work on this subject.

An accomplished photographer, Mr. Daintree exhibited a fine series of Photographs at the Edinburgh Meeting of the British Association in 1871, and read a short paper ${ }^{2}$ illustrated by them. His last scientific communication was read to the Geological Society of London on February 20 of this year. ${ }^{3}$

Richard Daintree was an enthusiastic man of science, and especially devoted himself to Geology, Chemistry, and Photography ; a man of great determination and strength of character; methodical and practical in all his habits; a genial companion, a true friend, and a most conscientious servant of the Crown. He has unfortunately passed from amongst us at a time when, had he retained his health, his vast knowledge of Australian Geology would have been of inestimable value to Science, especially to that branch to which he had more particularly devoted himself, the origin and occurrence of Gold. His memory will long linger in the minds of his many close and intimate friends, and in none more than those who had the pleasure of his acquaintance during the active years of his life, and who shared with him some of the dangers and difficulties of "bush life," which have, we fear, in a great measure tended to shorten the career of one of the most accomplished of Australian Geologists.

$$
\text { R. E., Jun. }
$$

1 Notes on the Geology of Queensland. By R. Daintree, F.G.S. With an Appendix, containing Descriptions of the Fossis, by R. Etheridge, F.R.S., and W. Carruthers, F.R.S. Quart. Journ. Geol. Soc. 1872, vol. xxviii. pp. 271-360, Maps and Plates, etc.

2 On the General Geology of Queensland. Brit. Assoc. Report for 1871, pt. 2, p. 95.

3 "Notes on Certain Modes of Occurrence of Gold in Australia." 